\title{
Comparison of Culture, Conventional and Real-time PCR Methods for Listeria monocytogenes in Foods
}

\author{
Dong-Hyeon Kim, Jung-Whan Chon*, Hyunsook Kim, Hong-Seok Kim, Dasom Choi, Young-Ji Kim, \\ Jin-Hyeok Yim, Jin-San Moon ${ }^{1}$, and Kun-Ho Seo \\ KU Center for Food Safety, College of Veterinary Medicine, Konkuk University, Seoul 143-701, Korea \\ ${ }^{1}$ Livestock Product Standard and Veterinary Epidemiology Division, \\ Animal, Plant and Fisheries Quarantine and Inspection Agency, Anyang 430-757, Korea
}

\begin{abstract}
We compared standard culture methods as well as conventional PCR and real-time PCR for the detection of Listeria monocytogenes (L. monocytogenes) in milk, cheese, fresh-cut vegetables, and raw beef that have different levels of background microflora. No statistical differences were observed in sensitivity between the two selective media in all foods. In total, real-time PCR assay exhibited statistically excellent detection sensitivity $(p<0.05)$ and was less time consuming and laborious as compared with standard culture methods. Conventional culture methods showed poor performance in detecting L. monocytogenes in food with high levels of background microflora, generating numerous false negative results. While the detection of $L$. monocytogenes in fresh cut vegetable by culture methods was hindered only by L. innocua, various background microflora, such as L. innocua, L. welshimeri, L. grayi, and Enterococcus faecalis appeared on the two selective media as presumptive positive colonies in raw beef indicating the necessity of improvement of current selective media. It appears that real-time PCR is an effective and sensitive presumptive screening tool for $L$. monocytogenes in various types of foods, especially foods samples with high levels of background microflora, thus complementing standard culture methodologies.
\end{abstract}

Keywords: Listeria monocytogenes, culture method, profiling of false-positive colonies, conventional PCR, real-time PCR

\section{Introduction}

Listeria monocytogenes is an emerging bacterial foodborne pathogen responsible for listeriosis, an illness characterized by meningitis, encephalitis, and septicemia (Churchill et al., 2006). Most countries have a zero tolerance policy toward the presence of L. monocytogenes in readyto-eat (RTE) foods owing to the possible severe consequences (Berrada et al., 2006; Jadhav et al., 2012; Yang et al., 2007). As such, the capability to detect L. monocytogenes in low numbers in food samples is essential.

Various methodologies, including conventional culture, molecular biological, biochemical, and immunological techniques, have been implemented for the rapid and specific detection of L. monocytogenes (Almeida and Almeida, 2000; Amagliani et al., 2006; Klein and Juneja, 1997;

*Corresponding author: Jung-Whan Chon, KU Center for Food Safety, College of Veterinary Medicine, Konkuk University, Seoul 143-701, Korea. Tel: +82-2-450-4121, Fax: +82-2-34364128, E-mail: kk2636@konkuk.ac.kr
Manzano et al., 1998; Solve et al., 2000; Wang and Hong, 1999). However, all methods are not well suited for routine use (Amagliani et al., 2006). The most commonly used reference methods for the detection of L. monocytogenes in foods worldwide are the ISO 11290 standards, which use conventional culture methods with selective and chromogenic media, Oxford agar, polymyxin-acriflavine-LiCl-ceftazidime-aesculin-mannitol (PALCAM) agar, and Agar Listeria Ottaviani Agosti (ALOA) (Churchill et al., 2006; ISO, 1996; Janzten et al., 2006). These methods can be used to detect $L$. monocytogenes at the level of 5-100 colony-forming units (CFU)/25 g of food; however, the presence of competing microflora such as Listeria innocua leads to false-negative results (Churchill et al., 2006; Scotter et al., 2001). Rapid and sensitive screening tests have been recommended for coupling with conventional culture methods to overcome this drawback (Han et al., 2008).

In this study, we compared the sensitivities and selectivities of 4 methods (culture on Oxford agar, culture on PALCAM agar, conventional polymerase chain reaction 
[PCR], and real-time PCR) of detecting L. monocytogenes to determine whether PCR assays could be used as an alternative rapid screening tool for L. monocytogenes in food samples. To determine the effect of background microflora on the detection of $L$. monocytogenes, we used food matrices composed of foods that have different background microflora levels and have been most commonly implicated in human listeriosis (Churchill et al., 2006; Gugnani, 1999; Meng and Doyle, 1997). In addition, we identified false-positive colonies that most commonly appeared on the 2 selective media, in order to obtain background information for the future development of improved culture media.

\section{Materials and Methods}

\section{Bacterial strains}

Twenty L. monocytogenes strains were used in this study. Most strains were originally obtained from the Food and Drug Administration (College Park, USA), and five standard strains were acquired from the American Type Culture Collection (ATCC). All L. monocytogenes strains were grown in tryptic soy broth (Difco Laboratories, USA) containing $0.6 \%$ yeast extract (Difco) for $18 \mathrm{~h}$ at $37^{\circ} \mathrm{C}$. In total, 42 non- $L$. monocytogenes spp. were streaked onto nutrient agar (Difco) for 2 passages and incubated in tryptic soy broth (Difco) for $24 \mathrm{~h}$ at $37^{\circ} \mathrm{C}$. All strains used in this study are listed in Table 1. For artificial inoculation into food samples, viable $L$. monocytogenes counts were obtained by serially diluting (10-fold) the overnight cultures in phosphate-buffered saline (PBS, pH 7.2, Difco) and plating $100 \mu \mathrm{L}$ of the dilutions on tryptic soy agar (Difco) containing $0.6 \%$ yeast extract.

\section{Sample preparation and inoculation of $L$. monocy- togenes}

Milk, cheese, fresh-cut vegetables, and raw beef with different matrices and background microflora levels were used to determine differences in the detection capabilities of culture methods through conventional and real-time PCR. All samples were purchased from a local retail market in Seoul, Korea. A mesophilic aerobic plate count was performed for uninoculated food samples to enumerate the background microflora in experimental food samples according to a previously described method (Chon et al., 2010).

L. monocytogenes ATCC 51776 was used in experimental inoculation testing. One milliliter of the inoculum was prepared via serial dilution of the overnight culture grown in $225 \mathrm{~mL}$ Listeria enrichment broth (Difco). The inoculum was then evenly inoculated into $500 \mathrm{~g}(\mathrm{~mL})$ of bulk samples via pipetting to generate partial positives and partial negatives for statistical comparison after division into subsamples. The inoculum levels ranged from 43 to $1,040 \mathrm{CFU}$ of $L$. monocytogenes for bulk samples. The inoculated bulk samples were subsequently divided into 20 subsamples of $25 \mathrm{~g}$ each. Two additional food samples ( $25 \mathrm{~g}$ each) were used as positive and negative controls. A positive control was prepared by spiking $25 \mathrm{~g}$ of the sample with approximately $10^{7} \mathrm{CFU} / \mathrm{mL}$ of $L$. monocytogenes ATCC 51776. As a negative control, uninoculated food $(25 \mathrm{~g})$ and sterilized PBS $(1 \mathrm{~mL})$ were prepared.

\section{Culture methods}

The detection of $L$. monocytogenes in the food samples by using culture was performed according to the methods described in ISO 11290-1 (ISO, 1996). After sample preparation and artificial inoculation of $L$. monocytogenes ATCC 51776, twenty-five grams of food was placed in $225 \mathrm{~mL}$ Listeria enrichment broth (Difco), homogenized in a BagMixer stomacher (Interscience, France) for $2 \mathrm{~min}$, and incubated at $30^{\circ} \mathrm{C}$ for $24 \mathrm{~h}$. Aliquots $(100 \mathrm{~mL})$ of these primary enrichments were transferred to $10 \mathrm{~mL}$ of a secondary enrichment Fraser broth (Difco) and incubated at $37^{\circ} \mathrm{C}$ for $24 \mathrm{~h}$. Enrichment broths were inoculated on Oxford agar (Oxoid, UK) and PALCAM agar (Oxoid) and incubated at $37^{\circ} \mathrm{C}$ for $24-48 \mathrm{~h}$. One typical graygreen colony with a black halo on Oxford and PALCAM agar on each plate was selected for biochemical confirmation using the Vitek 2 system (bioMerieux, France).

\section{DNA isolation}

Bacterial DNA templates were extracted as described by Seo and Brackett (2005) with some modifications. One-milliliter samples from pure cultures in PBS or food samples in secondary enrichment broth were centrifuged at 14,000 rpm for $3 \mathrm{~min}$. The pellets were washed in 1 $\mathrm{mL}$ of PBS and centrifuged at 14,000 rpm for $3 \mathrm{~min}$ and then resuspended in $200 \mu \mathrm{L}$ of PrepMan Ultra Reagent (Applied Biosystems, USA) and boiled for $10 \mathrm{~min}$. The samples were centrifuged at $14,000 \mathrm{rpm}$ for $3 \mathrm{~min}$. The supernatant was used for conventional and real-time PCR.

\section{Conventional PCR}

Specific primers derived from conserved sequences of the hly $A$ gene were used to test conventional PCR methods (Pagotto et al., 2002). The primer sequences were 5'- 
Table 1. Bacterial strains used in sensitivity and specificity tests

\begin{tabular}{|c|c|}
\hline Listeria monocytogenes strains & Non-Listeria monocytogenes strains \\
\hline Poly O Type 4 isolated from brie cheese & Listeria innocua isolated from meats $(\mathrm{n}=6)$ \\
\hline Serovar $4 \mathrm{~b}$ isolated from clinical sample & Listeria welshimeri isolated from meats $(\mathrm{n}=6)$ \\
\hline Poly O Type 1 isolated from ground veal & Staphylococcus aureus ATCC 6538 \\
\hline Poly O Type 1 isolated from flounder & Staphylococcus aureus isolated from beef \\
\hline Poly O Type 1 isolated from hamburger & Staphylococcus aureus isolated from chicken \\
\hline Poly O Type 1 isolated from sausage & Staphylococcus aureus isolated from pork $(\mathrm{n}=2)$ \\
\hline Poly O Type 1 isolated from monkfish & Enterobacter sakazakii FSM 145 \\
\hline Poly O Type 4 isolated from bovine tissue & Enterobacter sakazakii FSM 261 \\
\hline ATCC $51776^{1,3)}$ & Enterobacter sakazakii FSM 262 \\
\hline ScottA & Enterobacter sakazakii FSM 265 \\
\hline FSL-C1-109 & Enterobacter sakazakii FSM 270 \\
\hline 299056-A & Enterococcus faecalis isolated from beef $(\mathrm{n}=2)$ \\
\hline TS29/F2365 & Enterococcus faecalis isolated from pork $(\mathrm{n}=2)$ \\
\hline FSL-C1-122 & Enterococcus faecalis isolated from chicken \\
\hline 457778-1A & Salmonella Enteritidis D1 Serotype 3 \\
\hline FSL-J1-177 & Salmonella Enteritidis D1 Serotype 13A \\
\hline FSL-C1-056 & Salmonella Enteritidis D1 Serotype 24 \\
\hline CU-BR 1/93 & Salmonella Enteritidis Serotype 97 \\
\hline FSL-M1-004 & Salmonella Enteritidis D1 SerotypeS132 \\
\hline \multirow[t]{6}{*}{908260} & Escherichia coli $\mathrm{O} 157: \mathrm{H} 7(\mathrm{n}=5)^{2)}$ \\
\hline & Serratia odorifera I \\
\hline & Serratia marcesens \\
\hline & Enterobacter aerogenes ATCC $13048^{1)}$ \\
\hline & Citrobacter freundiiATCC $8090^{1)}$ \\
\hline & Proteus mirabilis ATCC 70021) \\
\hline
\end{tabular}

1) Obtained from American Type Culture Collection (ATCC).

2) Obtained from Centers for Disease Control and Prevention (CDC).

3) This strain was used in experimental inoculation testing.

Strains with no superscripts were obtained from the Food and Drug Administration.

CATTAGTGGAAAGATGGAATG-3' (primer A) and 5'GTATCCTCCAGAGTGATCGA-3' (primer B) and were used to amplify a 730-bp fragment. PCR was performed with the Takara Taq ${ }^{\mathrm{TM}}$ Hot Start Version (Takara Bio Inc., Japan), using a Biometra T-Personal thermal cycler (Biometra $\mathrm{GmbH}$, Germany). The reaction was performed at $94^{\circ} \mathrm{C}$ for $8 \mathrm{~min}$ for the initial denaturation, followed by 30 cycles each at $94^{\circ} \mathrm{C}$ for $1 \mathrm{~min}, 55^{\circ} \mathrm{C}$ for $1 \mathrm{~min}$, and $72^{\circ} \mathrm{C}$ for $2 \mathrm{~min}$, and then a final extension at $72^{\circ} \mathrm{C}$ for 2 min. In total, $5 \mu \mathrm{L}$ of amplified PCR product was analyzed with electrophoresis on a $1.5 \%$ agarose gel containing $50 \mu \mathrm{L}$ SafeView ${ }^{\mathrm{TM}}$ (Applied Biological Material Inc., Richmond, Canada) per liter. The amplified sequences were examined under ultraviolet light using a BioRad Molecular Imager ${ }^{\circledR}$ GelDoc $^{\mathrm{TM}}$ XR (BioRad Laboratories, USA).

\section{Real-time PCR}

The iap gene was targeted using the primers and probe according to the method described by Hein et al. (2001). The L. monocytogenes probe was labeled with 6-carbox- yfluorescein (FAM, the reporter dye) and 6-carboxytetramethylrhodamine (TAMRA, the quencher dye). The sequences for iap (amplicon size, 175 bases) were as follows: forward primer, 5'-CTA AAG CGG GAA TCT CCC TT-3'; reverse primer, 5'-CCA TTC TCT TGC GCG TTA AT -3'; and probe, 5'-FAM CCT CTG GCG CAC AAT ACG CTA GCA CT-3' TAMRA. The extracted DNA fluids $(5 \mu \mathrm{L})$ were transferred into $20 \mu \mathrm{L}$ of PCR mix consisting of $12.5 \mu \mathrm{L}$ TaqMan Universal PCR Master Mix (Applied Biosystems), forward primer $(2.5 \mu \mathrm{L}, 900 \mathrm{nM})$, reverse primer $(2.5 \mu \mathrm{L}, 900 \mathrm{nM})$, and TaqMan probe $(2.5$ $\mu \mathrm{L}, 250 \mathrm{nM}$ ). The 96-microwell plate was sealed with optical adhesive covers (Applied Biosystems) and was placed in an ABI-Prism 7500 sequence detector (Applied Biosystems). The reaction was run at $50^{\circ} \mathrm{C}$ for $2 \mathrm{~min}$ and then at $95^{\circ} \mathrm{C}$ for $10 \mathrm{~min}$, followed by 40 cycles each of $95^{\circ} \mathrm{C}$ for $15 \mathrm{~s}$ and $60^{\circ} \mathrm{C}$ for $60 \mathrm{~s}$.

\section{Sensitivity and specificity of $\mathbf{3}$ detection methods}

To determine the sensitivity and specificity of each test, 
a total of 62 strains $-20 L$. monocytogenes and 42 non- $L$. monocytogenes - were streaked onto Oxford and PALCAM agar. Plates yielding any colonies were considered positive regardless of the color and morphological features of the colonies. In parallel, conventional and realtime PCR were examined for pure cultures of these strains.

\section{Detection limits}

Detection limits were determined as described by Chon et al. (2012), with modification. To determine the detection limits of conventional and real-time PCR in PBS, we extracted genomic DNA from diluted overnight cultures containing $10^{8} \mathrm{CFU} / \mathrm{mL}$, as described above. The extracted DNA was then serially diluted (10-fold) in PBS. A total of $5 \mu \mathrm{L}$ of amplified PCR product was analyzed with electrophoresis as described earlier, and the cycle threshold value of the dilutions was measured with real-time PCR. The detection limits of conventional and real-time PCR were also measured in all foods used in this study. Inocula ( $1 \mathrm{~mL}$ each) containing $7.2 \times 10^{1}-1.2 \times 10^{8} \mathrm{CFU}$ of L. monocytogenes ATCC 51776 were serially inoculated into $10 \mathrm{~g}$ of food samples to yield a final L. monocytogenes concentration range of $7.2 \times 10^{0}-7.2 \times 10^{7} \mathrm{CFU} / \mathrm{g}$. Each inoculated sample was transferred into $90 \mathrm{~mL}$ of $0.85 \%$ saline water and homogenized for 1 min using a stomacher. Conventional and real-time PCR were performed with genomic DNA extracted from $1 \mathrm{~mL}$ of each diluted sample $\left(7.2 \times 10^{0}-7.2 \times 10^{7} \mathrm{CFU} / \mathrm{mL}\right)$ as previously described. The lowest bacterial count that yielded a positive reaction was considered the detection limit of conventional and real-time PCR.

\section{Statistical analysis}

The number of positives was compared in pairs using the McNemar test with SPSS Statics (ver 18.0, SPSS Inc., USA), and statistical differences were determined. Significant difference was reached when the $P$ value was less than 0.05 .

\section{Results and Discussion}

\section{Sensitivity and specificity of detection methods for various strains}

Data describing the sensitivity and specificity of 2 selective media, conventional PCR assay, and real-time PCR assay are presented in Table 2. Conventional and realtime PCR assays revealed no positive reaction with nonL. monocytogenes strains, providing sensitivity and specificity for the detection of L. monocytogenes at the species level. In contrast, L. innocua, Listeria welshimeri, and Enterococcus faecalis grew on the 2 selective media. All non-L. monocytogenes strains (6 each of L. innocua and $L$. welshimeri) and 3 of 5 E. faecalis strains (Table 2) grew on both selective media, forming the typical graygreen colony with a black halo. Firstenberg-Eden and She-

Table 2. Comparison of sensitivity (inclusivity) and specificity (exclusivity) of selective media and PCR methods using pure cultures of Listeria monocytogenes and non- L. monocytogenes strains

\begin{tabular}{|c|c|c|c|c|c|}
\hline & & \multicolumn{4}{|c|}{ No. of positive strains / total No. of strains tested (\%) } \\
\hline \multicolumn{2}{|c|}{ Strain } & \multicolumn{2}{|c|}{ Culture method } & \multirow{2}{*}{$\begin{array}{c}\text { Conventional } \\
\text { PCR }\end{array}$} & \multirow{2}{*}{$\begin{array}{c}\text { Real-time } \\
\text { PCR }\end{array}$} \\
\hline & & Oxford agar & PALCAM agar & & \\
\hline \multicolumn{2}{|c|}{ Listeria monocytogenes $^{1)}$} & $20 / 20(100)^{\mathrm{a}}$ & $20 / 20(100)^{\mathrm{a}}$ & $20 / 20(100)^{\mathrm{a}}$ & $20 / 20(100)^{\mathrm{a}}$ \\
\hline \multirow{13}{*}{$\begin{array}{c}\text { Non-Listeria } \\
\text { monocytogenes strains } 2 \text { ) }\end{array}$} & Listeria innocua & $6 / 6(100)$ & $6 / 6(100)$ & $0 / 6(0)$ & $0 / 6(0)$ \\
\hline & Listeria welshimeri & $6 / 6(100)$ & $6 / 6(100)$ & $0 / 6(0)$ & $0 / 6(0)$ \\
\hline & Staphylococcus aureus & $0 / 5(0)$ & $0 / 5(0)$ & $0 / 5(0)$ & $0 / 5(0)$ \\
\hline & Cronobacter spp. & $0 / 5(0)$ & $0 / 5(0)$ & $0 / 5(0)$ & $0 / 5(0)$ \\
\hline & Enterococcus faecalis & $3 / 5(60)$ & $3 / 5(60)$ & $0 / 5(0)$ & $0 / 5(0)$ \\
\hline & Salmonella spp. & $0 / 5(0)$ & $0 / 5(0)$ & $0 / 5(0)$ & $0 / 5(0)$ \\
\hline & Escherichia coli O157:H7 & $0 / 5(0)$ & $0 / 5(0)$ & $0 / 5(0)$ & $0 / 5(0)$ \\
\hline & Serratia odorifera & $0 / 1(0)$ & $0 / 1(0)$ & $0 / 1(0)$ & $0 / 1(0)$ \\
\hline & Serratia marcesens & $0 / 1(0)$ & $0 / 1(0)$ & $0 / 1(0)$ & $0 / 1(0)$ \\
\hline & Enterobacter aerogenes & $0 / 1(0)$ & $0 / 1(0)$ & $0 / 1(0)$ & $0 / 1(0)$ \\
\hline & Citrobacter freundii & $0 / 1(0)$ & $0 / 1(0)$ & $0 / 1(0)$ & $0 / 1(0)$ \\
\hline & Proteus mirabilis & $0 / 1(0)$ & $0 / 1(0)$ & $0 / 1(0)$ & $0 / 1(0)$ \\
\hline & Non-LM Total ${ }^{2,3)}$ & $15 / 42(35.7)^{\mathrm{c}}$ & $15 / 42(35.7)^{\mathrm{c}}$ & $0 / 42(0)^{\mathrm{d}}$ & $0 / 42(0)^{\mathrm{d}}$ \\
\hline
\end{tabular}

\footnotetext{
${ }^{1)}$ Different letters $(\mathrm{a}, \mathrm{b})$ within a row indicate a significant difference $(p<0.05)$ in sensitivity.

${ }^{2}$ Different letters $(\mathrm{c}, \mathrm{d})$ within a row indicate a significant difference $(p<0.05)$ in specificity.

${ }^{3)}$ Total number of non- L. monocytogenes strains.

PALCAM, polymyxin-acriflavine-LiCl-ceftazidime-aesculin-mannitol; PCR, polymerase chain reaction.
} 
lef (2000) first reported that certain enterococci formed typical colonies on PALCAM, thus demonstrating their capability to hydrolyze esculin. Marlene et al. (2001) have also demonstrated that PALCAM and Oxford media do not accommodate the differentiation of L. monocytogenes colonies and those of other Listeria species. Altho- ugh ALOA was not used in this study, the detection rate of $L$. monocytogenes on ALOA is also affected by the presence of L. innocua (Scotter et al. 2001). Our results correspond with those of these previous studies and suggest that rapid screening for L. monocytogenes should include PCRbased methodologies, which precisely differentiate $L$. monocytogenes from non-L. monocytogenes Listeria species (Table 2).

\section{Detection limits of PCR assays}

The detection limits of conventional and real-time PCR assays in pure culture and food samples are shown in Table 3. In pure cultures, more than $7.2 \times 10^{3} \mathrm{CFU}$ and 7.2 $\times 10^{2} \mathrm{CFU}$ of bacteria were required to achieve a positive reaction with conventional and real-time PCR, respectively (Table 3 ). Furthermore, for all food samples, more than $7.2 \times 10^{4} \mathrm{CFU}$ of bacteria was required for a positive reaction with conventional and real-time PCR (Table 3). The detection limits of conventional and real-time PCR have been reported to be influenced by the matrix or background microflora level of foods (Lee et al., 2010; McLauchlin et al., 2000; Tamarapu et al., 2001). However, in this study, the detection limits of L. monocytogenes with conventional and real-time PCR were identical in all foods studied.

\section{Identification of presumptively positive colonies on the 2 selective media}

The levels of background microflora and the confirmation of presumptive positive colonies on Oxford and PAL CAM agar obtained using the Vitek 2 system are presented in Table 4. As determined with aerobic plate counts, milk and cheese had less than $2 \mathrm{Log} C F U / \mathrm{mL}$ or $\mathrm{g}$ of background microflora. In the case of fresh-cut vegetables and raw beef, the counts of background microflora were 6.81 $\pm 0.28 \mathrm{Log} \mathrm{CFU} / \mathrm{g}$ and $4.00 \pm 0.17 \mathrm{Log} \mathrm{CFU} / \mathrm{g}$, respectively. In the case of milk and cheese, all suspicious L. monocytogenes colonies on both Oxford and PALCAM agar were confirmed as L. monocytogenes (29 of 29 in milk; 26 of 26 in cheese). Both media apparently detected

Table 3. Detection limits of Listeria monocytogenes ATCC 51776 with conventional and real-time PCR assays in pure culture and experimentally inoculated food samples without enrichment

\begin{tabular}{cccccccccccc}
\hline \hline \multirow{2}{*}{$\begin{array}{c}\text { Number of cells } \\
(\text { CFU/mL) }\end{array}$} & \multicolumn{3}{c}{ Pure culture } & \multicolumn{10}{c}{ Food samples } \\
\cline { 2 - 12 } & PCR & $\begin{array}{c}\text { Real-time } \\
\text { PCR }\end{array}$ & PCR & $\begin{array}{c}\text { Real-time } \\
\text { PCR }\end{array}$ & PCR & $\begin{array}{c}\text { Real-time } \\
\text { PCR }\end{array}$ & PCR & $\begin{array}{c}\text { Real-time } \\
\text { PCR }\end{array}$ & PCR & $\begin{array}{c}\text { Real-time } \\
\text { PCR }\end{array}$ \\
\hline $7.2 \times 10^{7}$ & + & + & + & + & + & + & + & + & + & + \\
$7.2 \times 10^{6}$ & + & + & + & + & + & + & + & + & + & + \\
$7.2 \times 10^{5}$ & + & + & + & + & + & + & + & + & + & + \\
$7.2 \times 10^{4}$ & + & + & + & + & + & + & + & + & + & + \\
$7.2 \times 10^{3}$ & + & + & - & - & - & - & - & - & - & - \\
$7.2 \times 10^{2}$ & - & + & - & - & - & - & - & - & - & - \\
$7.2 \times 10^{1}$ & - & - & - & - & - & - & - & - & - & - \\
$7.2 \times 10^{0}$ & - & - & - & - & - & - & - & - & - & - \\
\hline
\end{tabular}

ATCC, American Type Culture Collection; CFU, colony-forming units; PBS, phosphate-buffered saline; PCR, polymerase chain reaction.

Table 4. Identification of presumptively positive colonies on selective media using the Vitek 2 system

\begin{tabular}{|c|c|c|c|c|c|c|c|}
\hline \multirow{2}{*}{$\begin{array}{c}\text { Food } \\
\text { samples }\end{array}$} & \multirow{2}{*}{$\begin{array}{c}\text { No. of } \\
\text { background } \\
\text { microflora }{ }^{1)}\end{array}$} & \multirow{2}{*}{$\begin{array}{l}\text { No. of presumptively } \\
\text { positive plates / total } \\
\text { No. of samples tested }\end{array}$} & \multicolumn{5}{|c|}{$\begin{array}{l}\text { No. of plates confirmed by Vitek } 2 \text { system / } \\
\text { No. of presumptively positive plates (\%) }\end{array}$} \\
\hline & & & $\begin{array}{c}\text { Listeria } \\
\text { monocytogenes }\end{array}$ & $\begin{array}{l}\text { Listeria } \\
\text { innocua }\end{array}$ & $\begin{array}{c}\text { Listeria } \\
\text { welshimeri }\end{array}$ & $\begin{array}{l}\text { Listeria } \\
\text { grayi }\end{array}$ & $\begin{array}{l}\text { Enterococcus } \\
\text { faecalis }\end{array}$ \\
\hline Milk & $<2$ & $29 / 40$ & $29 / 29(100)$ & $0 / 29(0)$ & $0 / 29(0)$ & $0 / 29(0)$ & $0 / 29(0)$ \\
\hline Cheese & $<2$ & $26 / 40$ & $26 / 26(100)$ & $0 / 26(0)$ & $0 / 26(0)$ & $0 / 26(0)$ & $0 / 26(0)$ \\
\hline Vegetable salad & $6.81 \pm 0.28$ & $40 / 40$ & $15 / 40(37.5)$ & $25 / 40(62.5)$ & $0 / 40(0)$ & $040 /(0)$ & $0 / 40(0)$ \\
\hline Raw beef & $4.00 \pm 0.17$ & $40 / 40$ & 23 or $24^{2)} / 40(57.5)$ & $8 / 40(20)$ & $4 / 40(10)$ & $1 / 40(2.5)$ & 4 or $3^{3)} / 40(10)$ \\
\hline
\end{tabular}

${ }^{1)} \log$ colony-forming units (CFU)/g.

${ }^{2)} 23$ on Oxford agar and 24 on polymyxin-acriflavine-LiCl-ceftazidime-aesculin-mannitol (PALCAM) agar.

3) 4 on Oxford agar and 3 on PALCAM agar. 
L. monocytogenes effectively in foods with low levels of background microflora. However, for fresh-cut vegetables, only 15 of 40 suspicious colonies (37.5\%) on both media were confirmed to be of L. monocytogenes and 25 of 40 suspicious colonies $(62.5 \%)$ on both media were of L. innocua. In the case of raw beef, only 23 of 40 suspicious colonies $(57.5 \%)$ were confirmed as $L$. monocytogenes; 8 (20\%) were of $L$. innocua, 4 (10\%) were of $L$. welshimeri, $4(10 \%)$ were of E. faecalis, and $1(2.5 \%)$ was of Listeria grayi. Our results indicate that the detection of $L$. monocytogenes could be highly hindered by other Listeria spp. and Enterococcus spp. in food samples with high levels of background microflora. Although the count of background microflora in raw beef was lower than that in fresh-cut vegetables, a wider variety of nonL. monocytogenes colonies was notably observed on both Oxford and PALCAM media in fresh beef samples.

Of all meat products, raw minced meat has been reported to have the highest incidence of Listeria spp. - more than $86 \%$ positivity - which can be attributed either to fecal contamination during evisceration or to food handling (Fenlon et al., 1996; Yucel et al., 2005). In addition, fresh-cut vegetables are commonly contaminated with Listeria spp., which hinders the selective detection and isolation of L. monocytogenes with selective culture media (Little et al., 2007). The most prevalent background microflora in this study was L. innocua, which is known to produce a bacteriocin-like substance that inhibits the growth of L. monocytogenes during enrichment culture (Yokoyama et al., 1998). Listeria innocua also has a higher growth rate in selective liquid media than that of $L$. monocytogenes, resulting in a high number of false-negative results on PALCAM and Oxford media (Curiale and Lewus, 1994; MacDonald and Sutherland, 1994). In addition, E. faecalis strains, which are ubiquitous and can hydrolyze esculin, grew and formed a typical L. monocytogenes-like colony on Oxford and PALCAM agar in this study (Table 2) (Robin et al., 1997). While examining food samples with high levels of background microflora, random selection of presumptive positive colonies leads to a high chance of missing coexisting L. monocytogenes $(\mathrm{Cu}-$ riale and Lewus, 1994; MacDonald and Sutherland, 1994; Petran and Swanson, 1993).

We clearly showed that the standard culture methods present challenges for the detection of L. monocytogenes, especially in foods with high levels of background microflora. The culture methods should be improved by inhibiting the growth of non- $L$. monocytogenes strains such as L. innocua, L. welshimeri, E. faecalis, and L. grayi, espe- cially at the secondary enrichment step. No enrichment medium that selects $L$. monocytogenes over other Listeria spp. is currently available (Vlaemynck et al., 2000). Alternatively, other rapid and selective screening methods performed with the enrichment broth are required to reduce the risk of listeriosis.

\section{Comparison of detection methods for $L$. monocyto- genes in various food samples}

A comparison of the performance of the culture methods as well as that of conventional and real-time PCR in food samples is shown in Table 5. No positive reactions were obtained in the negative controls with the culture methods, conventional PCR, or real-time PCR, whereas all positive controls were detected as positives with all detection methods. Therefore, we conclude that samples used in the experiments were not naturally contaminated by $L$. monocytogenes. Significant differences were seen between real-time PCR and culture methods $(p<0.05)$ in the overall results (Table 5). Real-time PCR appears to have a higher detection capability than culture methods and conventional PCR assays for L. monocytogenes in foods, regardless of the matrix and count of background microflora.

In particular, conventional and real-time PCR assays provide more positives in the case of food samples such as fresh-cut vegetables and raw beef, which have high background microflora levels (Table 5). In fresh-cut vegetables, although both media revealed only 15 positives in 40 samples, conventional and real-time PCR yielded 18 and 22 positives, respectively, in 40 samples. This tendency was also found in the raw beef, in which 23 and 24 positives were found in 40 samples with Oxford and PAL CAM agar, respectively, and 25 and 27 positives with conventional and real-time PCR, respectively.

In food samples with high levels of background microflora, L. monocytogenes seemed likely to be partly missed by the culture methods, thus resulting in false negatives. To overcome this disadvantage, Vlaemynck et al. (2000) have suggested that using additional confirmation techniques immediately for the enriched broth might reduce the number of false negatives. Many novel techniques have been applied for the detection and screening of $L$. monocytogenes in food, including immuno-based method, molecular method, on-site analysis method (loop-mediated isothermal amplification), and biosensor-based techniques to date (Jadhav et al., 2012; Suh et al., 2014). PCRbased method, however, is still one of the most powerful screening methods for L. monocytogenes in food. 
Table 5. Comparison of culture methods, conventional PCR, and real-time PCR for the detection of Listeria monocytogenes in artificially inoculated food samples

\begin{tabular}{|c|c|c|c|c|c|c|}
\hline \multirow{3}{*}{$\begin{array}{c}\text { Food } \\
\text { samples }\end{array}$} & \multirow{3}{*}{ Trial No. } & \multirow{3}{*}{$\begin{array}{l}\text { Inoculum } \\
\text { (CFU/500g } \\
\text { of sample) }\end{array}$} & \multicolumn{4}{|c|}{ No. of positive samples / No. of samples tested (\%) } \\
\hline & & & \multicolumn{2}{|c|}{ Culture method } & \multirow{2}{*}{ Conventional PCR } & \multirow{2}{*}{ Real-time PCR } \\
\hline & & & Oxford agar & PALCAM agar & & \\
\hline \multirow{3}{*}{ Milk } & 1 & 43 & $11 / 20(55)$ & $11 / 20(55)$ & $11 / 20(55)$ & $12 / 20(60)$ \\
\hline & 2 & 107 & $18 / 20(90)$ & $18 / 20(90)$ & $18 / 20(90)$ & $19 / 20(95)$ \\
\hline & Total & & $29 / 40(72.5)$ & $29 / 40(72.5)$ & $29 / 40(72.5)$ & $31 / 40(77.5)$ \\
\hline \multirow{3}{*}{ Cheese } & 1 & 46 & $9 / 20(45)$ & $9 / 20(45)$ & $9 / 20(45)$ & $11 / 20(55)$ \\
\hline & 2 & 98 & $17 / 20(85)$ & $17 / 20(85)$ & $17 / 20(85)$ & $18 / 20(90)$ \\
\hline & Total & & $26 / 40(65)$ & $26 / 40(65)$ & $26 / 40(65)$ & $29 / 40(72.5)$ \\
\hline \multirow{3}{*}{$\begin{array}{l}\text { Vegetable } \\
\text { salad }\end{array}$} & 1 & 485 & $6 / 20(30)$ & $6 / 20(30)$ & $8 / 20(40)$ & $10 / 20(50)$ \\
\hline & 2 & 1040 & $9 / 20(45)$ & $9 / 20(45)$ & $10 / 20(50)$ & $12 / 20(60)$ \\
\hline & Total & & $15 / 40(37.5)$ & $15 / 40(37.5)$ & $18 / 40(45)$ & $22 / 40(55)$ \\
\hline \multirow{4}{*}{ Raw beef } & 1 & 450 & $13 / 20(65)$ & $13 / 20(65)$ & $14 / 20(70)$ & $15 / 20(75)$ \\
\hline & 2 & 113 & $10 / 20(50)$ & $11 / 20(55)$ & $11 / 20(55)$ & $12 / 20(60)$ \\
\hline & Total & & $23 / 40(57.5)$ & $24 / 40(60)$ & $25 / 40(62.5)$ & $27 / 40(67.5)$ \\
\hline & Grand total & & $93 / 160(58.13)^{*}$ & $94 / 160(58.75)^{*}$ & $98 / 160(61.25)$ & $109 / 160(68.13)$ \\
\hline
\end{tabular}

*Significantly difference compared with real-time PCR (McNemar test, $p<0.05$ ).

PALCAM, polymyxin-acriflavine-LiCl-ceftazidime-aesculin-mannitol; PCR, polymerase chain reaction.

Recently, there appears to have been an increasing interest in the improvement of the real-time PCR assays by enhancing sensitivity and reducing test time and cost (Gattuso et al., 2014; Rodriguez-Lazaro et al., 2014). In addition, the validation of real-time PCR in various food samples including soft cheese and pork has been conducted by comparing with ISO standard methods (Gattuso et al., 2014; Gianfranceschi et al., 2014). In these studies, realtime PCR methods showed higher performance in detecting L. monocytogenes compared to standard method. These results correspond with our study, suggesting that PCR assays, especially real-time PCR, are useful screening tools for the detection of L. monocytogenes in food samples, especially with high levels of background microflora.

In conclusion, our results indicate that more sophisticated and precise selective media should be developed for the detection of L. monocytogenes in foods with high levels of background microflora, especially fresh vegetables and meats. The results also suggest that real-time PCR could be an effective and sensitive presumptive screening tool for detecting L. monocytogenes in those food matrices. The limitations of the current study include lack of internal amplification controls (IAC) in PCR assays to rule out false negatives that might occur as a result of PCR inhibitors in the food matrix and samples of naturally contaminated foods. Therefore, further validation of PCR assays with IACs using more naturally contaminated foods is necessary in future studies.

\section{Acknowledgements}

This work was supported by the Animal, Plant and Fisheries Quarantine and Inspection Agency (no. 201103005) and the Export promotion Technology Development Program of iPET (no. 313010-3) funded by the Ministry for Food, Agriculture, Forestry, and Fisheries. Dong-Hyeon Kim, Jung-Whan Chon, Hong-Seok Kim, Dasom Choi, Young-Ji Kim, and Jin-Hyeok Yim are also partially supported by the Brain Korean 21 project from the Ministry of Education and Human Resources Development.

\section{References}

1. Almeida, P. F. and Almeida, R. C. C. (2000) A PCR protocol using inl gene as a target for specific detection of Listeria monocytogenes. Food Control 11, 97-101.

2. Amagliani, G., Giammarini, C., Omiccioli, E., Brandi, G., and Magnani, M. (2007) Detection of Listeria monocytogenes using a commercial PCR kit and different DNA extraction methods. Food Control 18, 1137-1142.

3. Amagliani, G., Omiccioli, E., Campo, A., Bruce, I. J., Brandi, G., and Magnani, M. (2006) Development of a magnetic capture hybridization-PCR assay for Listeria monocytogenes direct detection in milk samples. J. Appl. Microbiol. 100, 375383.

4. Berrada, H., Soriano, J., Pico, Y., and Manes, J. (2006) Quantification of Listeria monocytogenes in salads by real time quantitative PCR. Int. J. Food Microbiol. 107, 202-206.

5. Chon, J. W., Park, J. S., Hyeon, J. Y., Park, C., Song, K. Y., Hong, K. W., Hwang, I. G., Kwak, H. S., and Seo, K. H. (2012) Development of real-time PCR for the detection of Clostrid- 
ium perfringens in meats and vegetables. J. Microbiol. Biotechnol. 22, 530-534.

6. Churchill, R. L., Lee, H., and Hall, J. C. (2006) Detection of Listeria monocytogenes and the toxin listeriolysin $\mathrm{O}$ in food. J. Microbiol. Methods 64, 141-170.

7. Curiale, M. S. and Lewus, C. (1994) Detection of Listeria monocytogenes in samples containing Listeria innocua. $J$. Food Prot. 57, 1048-1051.

8. Firstenberg-Eden, R. and Shelef, L. A. (2000) A new rapid automated method for the detection of Listeria from environmental swabs and sponges. Int. J. Food Microbiol. 56, 231237.

9. Fenlon, D. R., Wilson, J., and Donachie, W. (1996) The incidence and level of Listeria monocytogenes contamination of food sources at primary production and initial processing. $J$. Appl. Bacteriol. 81, 641-650.

10. Gattuso, A., Gianfranceschi, M. V., Sonnessa, M., Delibato, E., Marchesan, M., Hernandez, M., De Medici, D., and Rodriguez-Lazaro, D. (2014) Optimization of a real time PCR based method for the detection of Listeria monocytogenes in pork meat. Int. J. Food Microbiol. 184, 106-108.

11. Gianfranceschi, M. V., Rodriguez-Lazaro, D., Hernandez, M., González-García, P., Comin, D., Gattuso, A., Delibato, E., Sonnessa, M., Pasquali, F., Prencipe, V., Sreter-Lancz, Z., Saiz-Abajo, M. J., Pérez-De-Juan, J., Butrón, J., Kozaèinski, L., Tomic, D. H., Zdolec, N., Johannessen, G. S., Jakoèiûnë, D., Olsen, J. E., De Santis, P., Lovari, S., Bertasi, B., Pavoni, E., Paiusco, A., De Cesare, A., Manfreda, G., and De Medici, D. (2014) European validation of a real-time PCR-based method for detection of Listeria monocytogenes in soft cheese. Int. J. Food Microbiol. 184, 128-133.

12. Gugnani, H. C. (1999) Some emerging food and water borne pathogens. J. Commun. Dis. 31, 65-72.

13. Han, S. R., Hyeon, J. Y., Kim, H. Y., Park, J. S., Heo, S., Shin, H. C., and Seo, K. H. (2008) Evaluation of conventional culture methods and validation of immunoassays for rapid detection of Listeria monocytogenes in dairy and processed foods. Korean J. Food Sci. An. 28, 616-622.

14. Hein, I., Klein, D., Lehner, A., Bubert, A., Brandl, E., and Wagner, M. (2001) Detection and quantification of the iap gene of Listeria monocytogenes and Listeria innocua by a new real-time quantitative PCR assay. Res. Microbiol 152, 37-46.

15. ISO (1996) Microbiology of food and animal feeding stuffs Horizontal method for the detection and enumeration of Listeria monocytogenes - Part 1: Detection method. International Standard ISO 11290-1. International Organization for Standardization. Geneva, Switzerland.

16. Jadhav, S., Bhave, M., and Palombo, E. A. (2012) Methods used for the detection and subtyping of Listeria monocytogenes. J. Microbiol. Methods. 88, 327-341.

17. Janzten, M. M., Navas, J., Corujo, A., Moreno, R., López, V., and Martínez-Suárez, J. V. (2006) Review. Specific detection of Listeria monocytogenes in foods using commercial methods: from chromogenic media to real-time PCR. Spanish $J$. Agr. Res. 4, 235-247.

18. Klein, P. G. and Juneja, V. K. (1997) Sensitive detection of viable Listeria monocytogenes by reverse transcription-PCR. Appl. Environ. Microb. 63, 4441-4448.

19. Lee, J. H., Song, K. Y., Hyeon, J. Y., Hwang, I. G., Kwak, H. S., Han, J. A., Chung, Y. H., and Seo, K. H. (2010) Comparison of standard culture method and real-time PCR assay for detection of Staphylococcus aureus in processed and unprocessed foods. Korean J. Food Sci. An. 30, 410-418.

20. Little, C. L., Taylor, F. C., Sagoo, S. K., Gillespie, I. A., Grant, K., and Mclauchlin, J. (2007) Prevalence and level of Listeria monocytogenes and other Listeria species in retail prepackaged mixed vegetable salads in the UK. Food Microbiol 24, 711-717.

21. Macdonald, F. and Sutherland, A. D. (1994) Important differences between the generation times of Listeria monocytogenes and Listeria innocua in two Listeria enrichment broths. J. Dairy Res. 61, 433-436.

22. Manzano, M., Cocolin, L., Cantoni, C., and Comi, G. (1998) Detection and identification of Listeria monocytogenes in food by PCR and oligonucleotide-specific capture plate hybridization. Food Microbiol. 15, 651-657.

23. Marlene, P., Solange, B., Cristina, M., Goncalo, A., Luisa, C., Paula, T., and Paul, A. G. (2001) Comparison of Oxford agar, PALCAM and Listeria monocytogenes Blood Agar for the recovery of $L$. monocytogenes from foods and environmental samples. Food Control. 12, 511-514.

24. Mclauchlin, J., Narayanan, G. L., Mithani, V., and O'Neill, G. (2000) The detection of enterotoxins and toxic shock syndrome toxin genes in Staphylococcus aureus by polymerase chain reaction. J. Food Prot. 63, 479-488.

25. Meng, J. and Doyle, M. P. (1997) Emerging issues in microbiological food safety. Annu. Rev. Nutr. 17, 255-275.

26. Pagotto, F., Corneau, N., Blais, B., and Phillippe, L. M. (2002) MFLP-78: Identification of presumptive positive Listeria monocytogenes from foods and environmental samples by the polymerase chain reaction. Official methods for the microbiological analysis of foods. Compendium of Analytical Methods, volume 3 Health Protection Branch.

27. Petran, R. L. and Swanson, K. M. J. (1993) Simultaneous growth of Listeria monocytogenes and Listeria innocua. J. Food Prot. 56, 616-618.

28. Robin, P., Jim, R. U., Peggy, K., Marlene, K. H., and Franklin, R. C. (1997) Multiplex PCR Detection of vanA, vanB, vanC-1, and vanC-2/3 Genes in Enterococci. J. Clin. Microbiol. 35, 703-707.

29. Rodriguez-Lazaro, D., Gonzalez-García, P., Gattuso, A., Gianfranceschi, M. V., and Hernandez, M. (2014) Reducing time in the analysis of Listeria monocytogenes in meat, dairy and vegetable products. Int. J. Food Microbiol. 184, 98-105.

30. Scotter, S. L., Langton, S., Lombard, B., Schulten, S., Nagelkerke, N., In'T Veld, P. H., Rollier, P., and Lahellec, C. (2001) Validation of ISO method 11290 Part 1 - detection of Listeria monocytogenes in foods. Int. J. Food Microbiol. 64, 295-306.

31. Seo, K. H. and Brackett, R. E. (2005) Rapid, specific detection of Enterobacter sakazakii in infant formula using a realtime PCR assay. J. Food Prot. 68, 59-63.

32. Solve, M., Boel, J., and Norrung, B. (2000) Evaluation of a 
monoclonal antibody able to detect live Listeria monocytogenes and Listeria innocua. Int. J. Food Microbiol. 57, 219224.

33. Suh, S. H., Dwivedi, H. P., Choi, S. J., and Jaykus, L. A. (2014) Selection and characterization of DNA aptamers specific for Listeria species. Anal. Biochem. 459, 39-45.

34. Tamarapu, S., Mckillip, J. L., and Drake, M. (2001) Development of a multiplex polymerase chain reaction assay for detection and differentiation of Staphylococcus aureus in dairy products. J. Food Prot. 64, 664-668.

35. Vlaemynck, G., Lafarge, V., and Scotter, S. (2000) Improvement of the detection of Listeria monocytogenes by the application of ALOA, a diagnostic, chromogenic isolation medium. J. Appl. Microbiol. 88, 430-441.

36. Wang, C. and Hong, C. (1999) A rapid PCR-based hybridiza- tion assay for the detection of Listeria monocytogenes in channel catfish. Food Microbiol. 16, 291-297.

37. Yang, H., Qu, L., Wimbrow, A. N., Jiang, X., and Sun, Y. (2007) Rapid detection of Listeria monocytogenes by nanoparticle-based immunomagnetic separation and real-time PCR. Int. J. Food Microbiol. 118, 132-138.

38. Yokoyama, E., Maruyama, S., and Katsube, Y. (1998) Production of bacteriocin-like-substance by Listeria innocua against Listeria monocytogenes. Int. J. Food Microbiol. 40, 133-137.

39. Yucel, N., Citak, S., and Onder, M. (2005) Prevalence and antibiotic resistance of Listeria species in meat products in Ankara, Turkey. Food Microbiol. 22, 241-245.

(Received 2014.5.29/Revised 2014.8.14/Accepted 2014.9.2) 